\title{
Factors Affecting the Release of Ascospores of Anisogramma anomala
}

\author{
J. N. Pinkerton, K. B. Johnson, J. K. Stone, and K. L. Ivors
}

First author: USDA-ARS, Horticultural Crops Research Laboratory, 3340 N.W. Orchard Avenue, Corvallis, OR 97330; second, third, and fourth authors: Department of Botany and Plant Pathology, Oregon State University, Corvallis 97330-2902.

Accepted for publication 13 November 1997.

\begin{abstract}
Pinkerton, J. N., Johnson, K. B., Stone, J. K., and Ivors, K. L. 1998. Factors affecting the release of ascospores of Anisogramma anomala. Phytopathology 88:122-128.

Relationships between environmental factors and release of ascospores of Anisogramma anomala, the causal agent of eastern filbert blight, were examined in four European hazelnut (Corylus avellana) orchards during a 2-year period. In each orchard, Burkhard volumetric spore traps and automated weather-monitoring equipment were deployed for 12-week periods beginning at budbreak, when hazelnut becomes susceptible to infection. Ascospores of A. anomala were released when stromata on the surface of hazelnut branches were wet from rain but not from dew. Release of ascospores ceased after branch surfaces dried. The duration of free moisture on branch surfaces regulated the initiation and rate of ascospore release, but no significant effects of temperature, relative humidity, wind, or light on ascospore release were apparent. Most (>90\%) ascospores were captured during precipitation events that exceeded $20 \mathrm{~h}$

in duration, which represented about $10 \%$ of the total precipitation events each season. Quantitative relationships between the hourly capture of $A$. anomala ascospores and hours since the beginning of a precipitation event were developed. With the onset of precipitation, the hourly rate of ascospore capture increased until the fifth hour of rain, remained relatively constant between the fifth and twelfth hours, and then declined gradually. During the 12-week spore-trapping periods, the likelihood and rates of ascospore release associated with precipitation were highest at budbreak and then declined through April and May until early June, when the reserve of ascospores in the perithecia was depleted. Large numbers of ascospores were captured in the volumetric spore traps, indicating that ascospores may be commonly dispersed long distances on air currents as well as locally by splash dispersal within the canopy, as reported previously. The results indicate that monitoring seasonal precipitation patterns may be useful for estimating the quantity and temporal distribution of airborne inoculum during the period that the host is susceptible to infection.
\end{abstract}

Eastern filbert blight, a canker and dieback disease caused by Anisogramma anomala (Peck) E. Müller in E. Müller \& Arx (Diaporthales), has become a major constraint in the production of European hazelnut (Corylus avellana L.) in the Pacific Northwest (15). A. anomala was found in southwestern Washington State in 1970 (6) and was probably introduced on hazelnut plants shipped from the eastern United States. Since then, the disease has spread southward through commercial plantings of European hazelnut and has become well established in the Willamette Valley of Oregon, where $98 \%$ of U.S. hazelnuts are grown $(10,27)$. The cankers and dieback caused by the disease have rendered many orchards unproductive within 3 to 8 years after the first infection is observed.

Knowledge of the biology and epidemiology of eastern filbert blight has expanded greatly during the last 5 years. Vegetative shoots of hazelnut are susceptible to infection in early spring after budbreak (16,31). Ascospores of $A$. anomala germinate on the epidermis of immature leaves and shoot tips, and hyphae penetrate directly (28). Approximately 1 year after infection, a canker develops at the site of infection $(10,31)$. In midspring, stromata form in the cankers; asci develop in late summer; and ascospores mature during the fall (9). Discharge of ascospores commences with the autumn rains and continues through the following spring $(9,11$, 25). Ascospores are released during periods of precipitation, but quantitative relationships between spore release and environmental factors are not well understood.

Corresponding author: J. N. Pinkerton; E-mail address: pinkertj@bcc.orst.edu

Publication no. P-1997-1215-01R

This article is in the public domain and not copyrightable. It may be freely reprinted with customary crediting of the source. The American Phytopathological Society, 1998.
Mechanisms of spore release and the environmental factors affecting spore release have been examined for many plantpathogenic fungi (14). An array of factors that affect the release of spores has been identified, including rainfall and free water $(4,14,21,30,32)$, temperature $(3,22,33)$, humidity $(12,20,32)$, light $(5,13,18,21,24)$, vibration (18), and electrostatic charge (19). Ascospores of many fungi are released only after the ascostroma is hydrated by free moisture or high relative humidity $(1,8,9)$. Upon hydration, the asci swell, increasing the pressure in the centrum and forcing asci through the ostiole, where ascospores are forcibly ejected (2,9). Many ascomycetes, such as Venturia inaequalis (Cooke) G. Wint., eject spores into the air, while both splash and air dispersal has been reported for other ascomycetes (3).

Disease-warning models based on the measurement of meteorological variables have been developed that predict when inoculum will be available or when weather conditions will be conducive for infection (7). These models have been used for timing management activities, such as the application of fungicides. However, quantitative information describing relationships between meteorological parameters and the release of $A$. anomala ascospores has not been available for development of eastern filbert blight management programs. The objectives of this study were to examine release of ascospores of $A$. anomala in relation to environmental factors and to use data to develop quantitative relationships concerned with the likelihood and magnitude of sporerelease events.

\section{MATERIALS AND METHODS}

Spore trapping. Release of ascospores of A. anomala was studied for 2 years during the period from budbreak (mid-March), when the hazelnut first becomes susceptible to infection $(16,31)$, through June. In 1992, budbreak occurred on 15 March (day of year [DOY] 74) in a 5-year-old orchard of the highly susceptible 
cultivar Ennis (26) located in Columbia County, Oregon, and on 8 March (DOY 68) in an unmanaged, mature orchard of the moderately susceptible cultivar Barcelona (26) located in Clackamas County, Oregon. A 7-day recording volumetric spore trap (Burkhard Scientific, Rickmansworth, Hertfordshire, England) was positioned in the center of the Columbia County orchard with the air-intake orifice at midcanopy height, $1.25 \mathrm{~m}$ above the ground, and $1.5 \mathrm{~m}$ from the surrounding trees. At the Clackamas County site, the trap was placed on a platform in the middle of a severely diseased tree. The air-intake orifice was $3 \mathrm{~m}$ above the ground, the elevation at which the majority of sporulating cankers in the tree were located. On 10 March 1993 (DOY 69), Burkhard traps were placed in the center of two mature, unmanaged orchards of cultivar Barcelona. One orchard again was in Clackamas County, and the second was in Multnomah County, Oregon. Each trap was positioned between two tree rows, approximately $2.5 \mathrm{~m}$ from the surrounding trees. Because a large proportion of sporulating cankers occurred on shoots 2 to $3 \mathrm{~m}$ high at the base of the trees, the traps were positioned with the orifices $1.5 \mathrm{~m}$ above the ground. The Burkhard traps were powered by $12-\mathrm{V}$ batteries and adjusted to sample $0.6 \mathrm{~m}^{3}$ of air per hour.

Burkhard collection tapes were changed and processed weekly. In the lab, the tapes were cut into daily (48- $\mathrm{mm}$ ) sections, mounted on microscope slides, and stained in aniline blue $(30 \mathrm{mg}$ of aniline blue, $20 \mathrm{ml}$ of deionized water, $10 \mathrm{ml}$ of glycerol, and $10 \mathrm{ml}$ of lactic acid). Tapes holding trapped spores were further divided into $2-\mathrm{mm}$ segments representing 1 -h periods. The tapes were examined microscopically at $250 \times$ for ascospores of $A$. anomala. During precipitation events and 1 day before and after precipitation was recorded, tapes were scanned twice along two parallel axes; A. anomala spores were easily distinguished from other spores of similar size and shape because of the distinctive apical cell (9). However, during extended periods without precipitation, because ascospores were never collected, the tape segments were scanned only once along the long axis of each hourly interval. The concentration of ascospores in the air was calculated by accounting for the proportion of the tape examined and the volume of air sampled.

Early in the study, it was observed that ascospores of $A$. anomala were usually clustered together in groups on the spore collection tapes. To determine the extent of clustering, the number of spores and their proximity to one another were recorded for eight 1 -h periods in two orchards during which at least 400 spores were collected. All spores $<10 \mu \mathrm{m}$ (one spore length) from each other were considered to be within the same cluster. The frequencies of single spores, clusters of two to six spores, and clusters of more than seven spores in each hourly segment of tape were determined.

Environmental monitoring. Meteorological data were collected at each orchard with data loggers (CR21X, Campbell Scientific, Logan, UT) programmed to read sensors at 5-s intervals and to record average values at $1-\mathrm{h}$ intervals. The data loggers were equipped with a temperature and relative humidity sensor (model 207, Phys-Chem Scientific, New York, NY), which was placed in the canopy of a tree. A tipping bucket rain gauge (model TE 525, Texas Electronics, Dallas, TX) was placed in an open area between the trees. Wind speed and direction sensors (model 039, Met One, Grants Pass, OR) were placed at canopy height in each orchard. In addition, a branch wetness sensor, constructed of paired strands of 22-gauge copper spaced 3 to $4 \mathrm{~mm}$ apart and wrapped tightly around a $15-\mathrm{cm}$ section of a cankered hazelnut branch, was placed in the canopy of a tree in each orchard. This sensor was calibrated by wetting the branch with water to runoff and recording the electrical resistance as the water dried. The wetdry threshold was defined as the resistance recorded when water placed on the surface of the branch was no longer visible and the color of the bark was similar to that of dry branches; this resistance was 60 kohms. Once each week, the calibration of the relative humidity and temperature sensors was checked against an aspirated wet-dry bulb thermometer (model 566, Belfort Instrument, Baltimore, MD).

Data analysis. For the initial analysis of patterns of ascospore capture, daily means for temperature, relative humidity, branch wetness resistance, and wind speed were obtained by averaging hourly records. In addition, the number of hours with precipitation, the number of hours branches were wet, the mean intensity of precipitation $(\mathrm{mm} / \mathrm{h})$, and the maximum intensity of precipitation $(\mathrm{mm} / \mathrm{h})$ were tabulated for each day. Daily data were summarized for each orchard and then combined into a single data set for analysis. Average daily spore density $\left[\log _{10}\left(\operatorname{ascospores} / \mathrm{m}^{3}\right)\right]$ was correlated with the environmental variables recorded on the same day and for each of the four preceding days by using the SAS GLM procedure, version 6.0 (SAS Institute, Cary, NC). Spore density also was regressed on the mean daily environmental variables with a forward stepwise regression procedure (SAS). Variables with a partial $F$ statistic significant at $P \leq 0.05$ were retained in the model. In addition, for hours during which precipitation was recorded, hourly values of spore density were correlated with hourly means of temperature, wind speed, and amount of precipitation.

To examine the effect of the duration of a precipitation event on ascospore capture, the number of spores captured during each hour since the beginning of each precipitation event was determined. For this purpose, a precipitation event was defined as a continuous series of hours during which the individual hours in the event met one of these criteria: rain occurred, the branch was wet and rain occurred during the following hour, or the branch was wet and rain occurred during at least one of the two preceding hours. This definition corrected for brief, intermittent breaks from rain and was reasonable considering precipitation patterns in western Oregon. Hourly means of spore density from each orchard were regressed on hours since the beginning of a precipitation event by using polynomial functions. Orchard means for the proportion of hours during which ascospores were collected and proportion of the seasonal ascospore total collected during each hour during precipitation events were regressed similarly.

The relationship between ascospore capture, duration of precipitation events, and date within the spore-trapping period was examined by using the same hourly data set. For this purpose, the data were divided into 10-day periods starting at DOY 70 and ending at DOY 150. Within each 10-day period, hourly ascospore density and the proportion of hours during which spores were collected were averaged for each hour since the beginning of a precipitation event. Mean values of these dependent variables were then plotted as a two-variable function of seasonal period and hours since the beginning of a precipitation event by using response surface software, version 6.0 (NCSS, Kaysville, UT).

\section{RESULTS}

Patterns of ascospore release. The effects of various environmental variables on ascospore capture during a representative 16day period are presented in Figure 1. Ascospores were collected initially during the first or second hour of a precipitation event and continued to be collected as long as rain persisted. Generally, ascospores were not collected if the branch was wet from dew (e.g., the mornings of days 95 and 102 in Figure 1). During periods of intermittent rain, ascospores were captured up to $5 \mathrm{~h}$ after precipitation ended if the branch remained wet, but if the branch dried between precipitation events, spores were not collected until the next rain was recorded. For example, from DOY 95 to DOY 100 in Figure 1, there were four precipitation events separated by 7 to $10 \mathrm{~h}$ without rain. In these cases, spores were collected shortly after the start of precipita- 
tion, but collection stopped when the branches dried. A higher proportion of spores were collected at night than during the day because most of the precipitation occurred at night. Relative humidity and temperature oscillated daily, but temperature was generally lower and relative humidity higher during precipitation events.

Among orchards, branches were wet and precipitation occurred an average of $590 \pm$ (standard deviation) $50 \mathrm{~h}$ and $325 \pm 111 \mathrm{~h}$, respectively, of the 80 days that the spore traps operated at each location. At each site, $>72 \%$ of the spores were collected during two major rain storms, and $>83 \%$ of the spores were collected during three major storms (Table 1). Moreover, $>62 \%$ of the seasonal ascospore totals were captured during $10 \mathrm{~h}$ within these storms. The average duration of these major rain storms was $26 \mathrm{~h}$, while the average duration for all precipitation events was $7 \mathrm{~h}$. An average of 5.3 precipitation events exceeded $20 \mathrm{~h}$ in each orchard. The average duration of precipitation events during which spores were collected was $19 \mathrm{~h}$, while the average duration of precipitation events during which spores were not collected was $5 \mathrm{~h}$ (Table 1). Occasionally, spores were collected without precipitation or branch wetness (Table 1), but ascospores captured without corresponding branch wetness represented only $0.15 \%$ of the seasonal totals.

Correlation analysis also indicated a strong relationship between spore release and precipitation. Daily averages of spore density were correlated $(P \leq 0.01)$ with all precipitation and wetness variables measured on the same day (Table 2). In contrast, spore density was not correlated significantly $(P>0.05)$ with mean daily temperature or with daily values of mean hourly or maximum hourly wind speed. Correlations of spore density with the environmental variables recorded on the preceding day were weak (Table 2), and those with environmental variables recorded on the preceding 2 to 4 days were not significant. Stepwise regres- sion of spore density on multiple environmental variables resulted in the following model:

$$
S=-0.44+0.057 P_{\mathrm{h}}+0.087 B_{\mathrm{w}}+0.097 T-0.043 W_{\mathrm{mx}}+0.13 P_{\mathrm{mx}}
$$

$R^{2}=0.46$, where $S=$ daily average of $\log _{10}\left(\right.$ spores $\left./ \mathrm{m}^{3}\right), P_{\mathrm{h}}=$ number of hours of precipitation per day, $B_{\mathrm{w}}=$ number of hours that branches were wet per day, $T=$ mean daily temperature, $W_{\mathrm{mx}}=$ maximum hourly wind speed per day, and $P_{\mathrm{mx}}=$ mean hourly intensity of precipitation per day. The partial coefficients of determination for variables entering the model $(P \leq 0.05)$ were 0.30 for $P_{\mathrm{h}}, 0.048$ for $B_{\mathrm{w}}, 0.045$ for $T, 0.039$ for $W_{\mathrm{mx}}$, and 0.023 for $P_{\mathrm{mx}}$. No environmental parameters measured on a day preceding the day that spores were collected added significantly to the model.

Additional correlation analysis among hourly meteorological measurements and ascospore collections failed to identify other factors that modified the rate of ascospore release during periods of precipitation. Hourly measures of intensity of precipitation and the amount of precipitation were positively but only weakly correlated ( $r=0.078$ to 0.12 ) with hourly spore density; these correlations increased marginally when precipitation events $>20 \mathrm{~h}$ in duration were examined ( 21 events; $r=0.004$ to 0.43 ). Neither mean temperature nor mean wind speed measured in hours with rain were correlated $(r \leq 0.038)$ with ascospore capture. These data indicate that precipitation resulting in prolonged branch wetness, regardless of the amount or intensity of precipitation, was the major environmental factor affecting ascospore release.

Clustering of trapped ascospores. Ascospores of A. anomala on spore-collection tapes were usually found in clusters, as defined by distances of $<10 \mu \mathrm{m}$ between spores. Sixty percent of the clusters contained seven to eight spores, and $34 \%$ of clusters contained two to six spores; $6 \%$ of the collected spores were isolated (i.e., $>10 \mu \mathrm{m}$ ) from other ascospores of $A$. anomala. Intact or ruptured asci were not observed in asso-

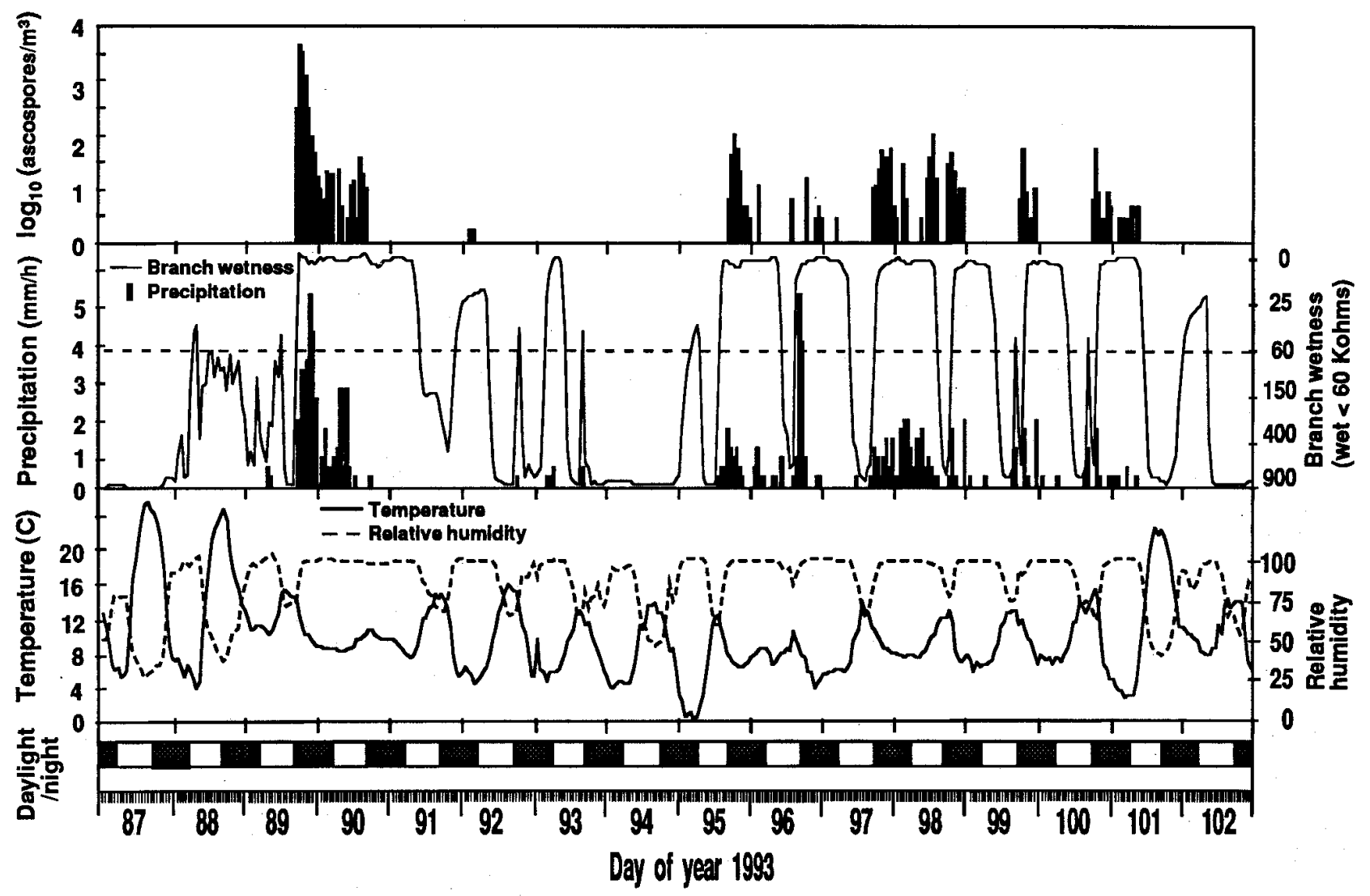

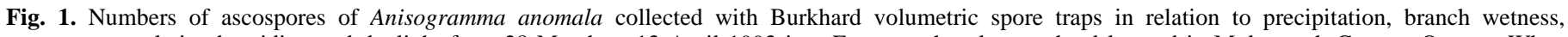

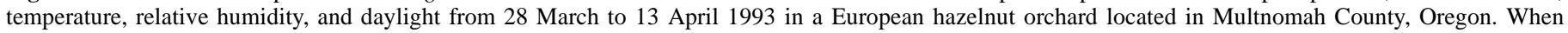
branches were wet, the electrical resistance of a branch wetness sensor was $<60$ kohms. 
ciation with the spore clusters, but no spore cluster contained more than eight spores.

Effect of duration of rain events. Ascospore capture was varied among precipitation events and locations, but after the spore density was compared with hours since the beginning of a precipitation event, consistent patterns of spore release during precipitation events were observed (Fig. 2A-D). The proportion of hours during which spores were captured increased with each consecutive hour of the event to approximately $25 \mathrm{~h}$ (Fig. 2B). Similarly, spore density increased rapidly until the fifth hour of an event, remained relatively constant between the fifth and twelfth hours, and then declined gradually after the twelfth hour (Fig. 2C). The highest proportions of the seasonal ascospore total also occurred between the fifth and twelfth hours of precipitation events, after which proportions of the seasonal ascospore total declined rapidly (Fig. 2D).

Seasonal pattern of ascospore release. The proportion of hours during which ascospores were collected during precipitation was highest near budbreak and then declined as the season progressed. For example, during the tenth hour of precipitation events from DOY 70 to DOY 90, the Burkhard traps collected ascospores of $A$. anomala during $50 \%$ of the recorded hours compared with only $11 \%$ for the tenth hour of precipitation events from DOY 130 to 150 (Fig. 3). This seasonal decrease in the proportion of hours during which spores were collected was apparent for all hours of precipitation events (Fig. 3). Similarly, the number of spores col-

TABLE 1. Statistics on precipitation events and branch wetness in four European hazelnut orchards located in western Oregon during which ascospores of Anisogramma anomala were collected with Burkhard volumetric spore traps during the springs of 1992 and $1993^{\mathrm{a}}$

\begin{tabular}{|c|c|c|c|c|}
\hline \multirow[b]{2}{*}{ Environmental factor } & \multicolumn{2}{|c|}{$1992^{\mathrm{b}}$} & \multicolumn{2}{|c|}{$1993^{b}$} \\
\hline & Site 1 & Site 2 & Site 3 & Site 4 \\
\hline Total hours of precipitation & 434 & 406 & 242 & 217 \\
\hline Total hours that branches were wet ${ }^{c}$ & 619 & 641 & 530 & 569 \\
\hline \multicolumn{5}{|l|}{$\begin{array}{l}\text { Maximum percentage of seasonal ascospore } \\
\text { total collected during }\end{array}$} \\
\hline $1 \mathrm{~h}$ & 20 & 11 & 30 & 9 \\
\hline 5 individual hours & 67 & 47 & 69 & 41 \\
\hline 10 individual hours & 79 & 77 & 79 & 62 \\
\hline 1 precipitation event & 79 & 46 & 59 & 55 \\
\hline 2 precipitation events & 83 & 90 & 76 & 72 \\
\hline 3 precipitation events & 86 & 97 & 84 & 87 \\
\hline \multicolumn{5}{|l|}{ Average duration of precipitation events (h) } \\
\hline All events & 8 & 8 & 8 & 5 \\
\hline $\begin{array}{l}3 \text { events during which most } \\
\text { ascospores were collected }\end{array}$ & 28 & 31 & 23 & 23 \\
\hline When ascospores were collected & 20 & 21 & 17 & 18 \\
\hline When ascospores were not collected & 4 & 5 & 4 & 5 \\
\hline \multicolumn{5}{|l|}{ Total number of precipitation events } \\
\hline All events & 75 & 68 & 52 & 53 \\
\hline Events $>20 \mathrm{~h}$ & 6 & 4 & 6 & 5 \\
\hline \multicolumn{5}{|l|}{$\begin{array}{l}\text { Percentage of seasonal ascospore total } \\
\text { collected during }\end{array}$} \\
\hline Precipitation events $>20 \mathrm{~h}$ & 91 & 90 & 90 & 93 \\
\hline Branch wetness periods $>20 \mathrm{~h}$ & 98 & 98 & 90 & 94 \\
\hline \multicolumn{5}{|l|}{$\begin{array}{l}\text { Total hours ascospores were collected } \\
\text { without recorded }\end{array}$} \\
\hline Precipitation & 16 & 5 & 9 & 36 \\
\hline Branch wetness & 4 & 3 & 4 & 22 \\
\hline \multicolumn{5}{|l|}{$\begin{array}{l}\text { Percentage of seasonal ascospore total } \\
\text { collected without recorded }\end{array}$} \\
\hline Precipitation & 1.2 & 0.2 & 0.3 & 0.2 \\
\hline Branch wetness & 0.3 & 0.0 & 0.1 & 0.2 \\
\hline
\end{tabular}

${ }^{a}$ Burkhard volumetric spore traps were run continuously from 8 March to 1 June in 1992 and from 15 March to 1 June in 1993.

${ }^{b}$ In 1992, the site 1 orchard was located in Columbia County and the site 2 orchard was in Multnomah County. In 1993, the site 3 orchard was located in Multnomah County and the site 4 orchard was in Clackamas County.

c When branches were wet, the electrical resistance of a branch wetness sensor was $<60$ kohms. lected per hour also showed a seasonal pattern (Fig. 4). The highest counts of ascospores collected per hour occurred between DOY 70 and DOY 90. Most of these spores were collected from the fifth to the twelfth hours of precipitation; up to 4,200 spores per cubic meter were measured during the tenth hour of precipitation at one location. After DOY 120, few spores were collected after the sixteenth hour of precipitation (Figs. 3 and 4), and after DOY 140, the mean concentration of ascospores of $A$. anomala in air sampled during precipitation events declined to fewer than three spores per cubic meter (Fig. 4).

\section{DISCUSSION}

The spread of eastern filbert blight in commercial hazelnut orchards in the Pacific Northwest has provided reason to develop a thorough understanding of its epidemiology. Central to this understanding has been an effort to describe quantitatively the effect of environmental factors on the release of ascospores and the temporal availability of inoculum. Previously, the release of ascospores of A. anomala was reported to be associated with periods of precipitation (11). In that study, glass slides were placed over stromata on tree branches to study patterns of ascospore release. This method provided qualitative data on spore release, but it did not quantify the relationship between specific environmental conditions and the timing and numbers of spores released. On the basis of the distribution of ascospores of A. anomala on glass slides and the absence of ascospores in a Burkhard volumetric trap placed in the same orchard, Gottwald and Cameron (11) concluded that the ascospores were splash dispersed. This conclusion was consistent with the presence of ascospores in the copious mucilage discharged from the perithecia of A. anomala upon hydration. In contrast, during periods of precipitation, we collected large numbers of ascospores of $A$. anomala with volumetric spore traps, and we did not observe a correlation between ascospore density and precipitation intensity, which is common with splash-dispersed spores (23). Burkhard traps sample air as opposed to splash drops and consequently provide strong evidence that ascospores of $A$. anomala are discharged actively into the air. Perithecia of $A$. anomala are characterized by a long beak and a narrow, restricted ostiole. At maturity, most asci are free floating within the perithecial locule. The fact that the majority of ascospores of $A$. anomala were deposited on the Burkhard collection tapes in groups of seven or eight suggests that ascospores are discharged in octets and that individual spores from the same ascus adhere to each other.

TABLE 2. Correlation of daily capture of ascospores ${ }^{\mathrm{a}}$ of Anisogramma anomala with daily averages of environmental variables measured in four European hazelnut orchards located in western Oregon during the springs of 1992 and 1993

\begin{tabular}{lcc}
\hline & \multicolumn{2}{c}{ Correlation coefficients } \\
\cline { 2 - 3 } Environmental variable & $\begin{array}{c}\text { Current } \\
\text { day }\end{array}$ & $\begin{array}{c}\text { Previous } \\
\text { day }\end{array}$ \\
\hline Precipitation $(\mathrm{mm} /$ day) & $0.50^{* *}$ & $0.26^{* *}$ \\
Precipitation $(\mathrm{h} /$ day) & $0.25^{* *}$ & 0.10 \\
Average rain intensity $(\mathrm{mm} / \mathrm{h})$ & $0.25^{* *}$ & 0.10 \\
Maximum rain intensity $(\mathrm{mm} / \mathrm{h})$ & $0.50^{* *}$ & $0.21^{* *}$ \\
Mean daily branch wetness sensor value $(\mathrm{kohm})$ & $0.49^{* *}$ & $0.18^{*}$ \\
Branch wetness $(\mathrm{h} /$ day) & $0.41^{* *}$ & $0.16^{*}$ \\
Mean relative humidity & $0.35^{* *}$ & 0.00 \\
Mean temperature $\left({ }^{\circ} \mathrm{C}\right)$ & 0.02 & 0.01 \\
Mean wind speed $(\mathrm{m} / \mathrm{s})$ & -0.04 & -0.02 \\
Maximum hourly wind speed $(\mathrm{m} / \mathrm{s})$ & -0.02 & -0.01 \\
\hline
\end{tabular}

${ }^{a}$ Burkhard volumetric spore traps were run continuously in each of four diseased hazelnut orchards from 8 or 15 March to 1 June 1992 and from 10 March to 1 June 1993. For analysis, hourly counts of ascospores were transformed $\log _{10}\left(\right.$ ascospores $\left./ \mathrm{m}^{3}\right)$ and then averaged to provide a daily value.

b $* *$ and $*=$ significant at $P=0.01$ and 0.05 , respectively. 
Most likely, ascospores of A. anomala can be either ejected actively into air currents or dispersed passively by water runoff down branches or by splash droplets after rain impacts on the stromatal surface. These dual dispersal mechanisms have been reported for other ascomycetes $(3,29,32)$. Ascospores of $A$. anomala that are discharged actively into the air may account for most of the tree-to-tree and long-distance spread of the disease, while ascospores dispersed by rain splash may give rise to many of the secondary infections that occur within tree canopies.

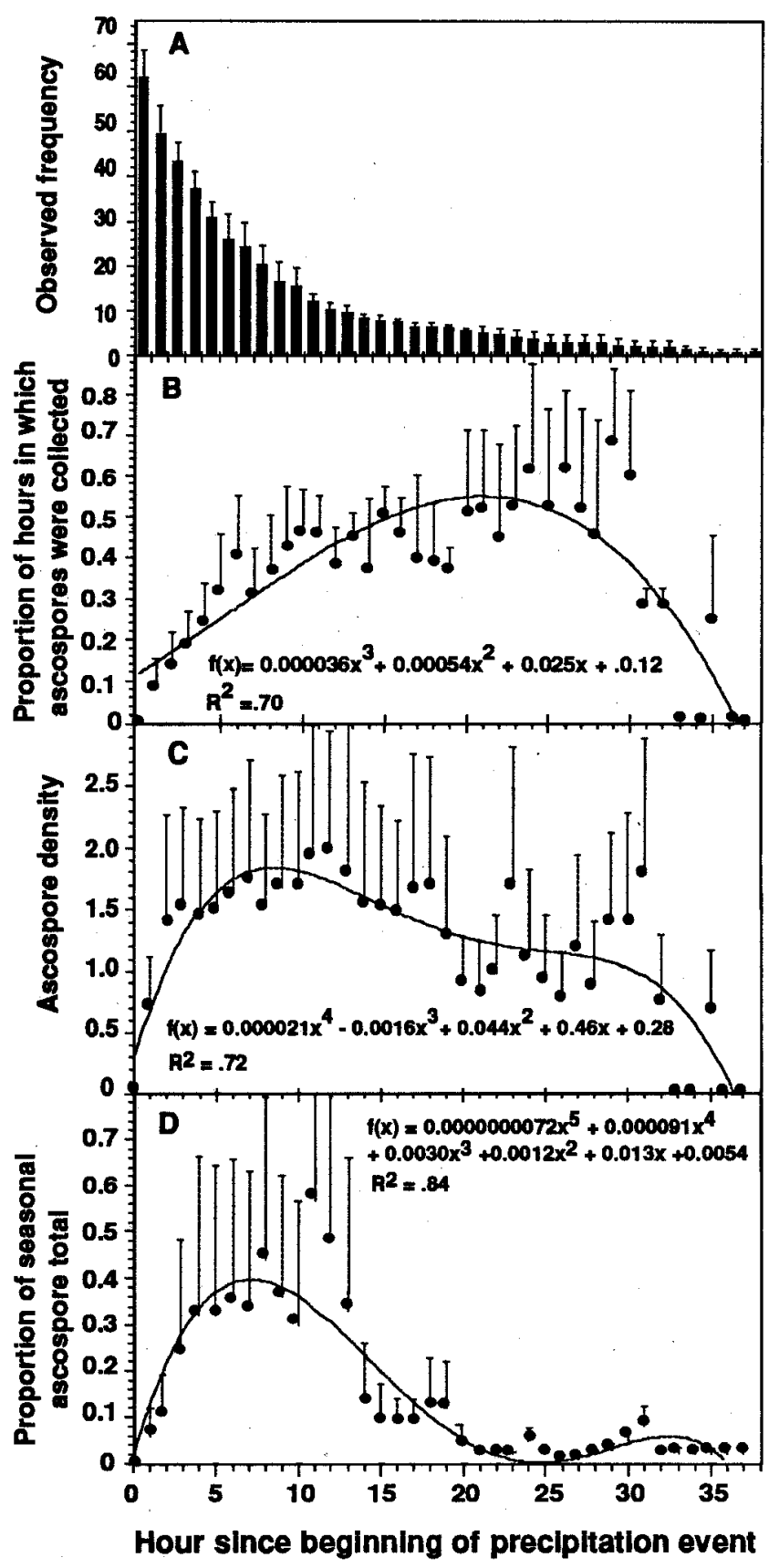

Fig. 2. Variables related to the collection of ascospores of Anisogramma anomala in Burkhard volumetric spore traps in relation to hours since the beginning of a precipitation event. Data are mean values of 243 precipitation events that were monitored in four European hazelnut orchards in the northern Willamette Valley of Oregon from about 10 March to 1 June in 1992 and 1993. A, Frequency with which the independent variable, hours since the beginning of a precipitation event, was observed. B, Proportion of hours during which ascospores were collected. C, Ascospore density $\left[\log _{10}\left(\operatorname{ascospores} / \mathrm{m}^{3}\right)\right]$. D, Proportion of the seasonal ascospore total collected during each hour since the beginning of a precipitation event. Error bars represent the standard error of the mean among orchards.
Many ascomycetes release spores in response to changes in the amount of moisture in the environment, including changes in relative humidity, dew, and precipitation $(1,3,8,12,21,30,32,33)$. $A$. anomala also requires free moisture to initiate and maintain the release of ascospores. After the stromata is wetted by rain, the hydrophilic mucilage and the asci within the perithecia hydrate and swell, increasing the pressure in the centrum $(9,14)$. After several hours of wetting, this pressure is released by expulsion of part of the perithecial contents (9). Although data are not available on the rate of hydration and increase in pressure in the perithecia, the hourly spore-trapping data indicates that, on average, the perithecia do not become fully hydrated until wetted continuously for 3 to $5 \mathrm{~h}$, after which time the maximum rate of spore capture occurred (Fig. 2C). The release of spores continued as long as the perithecia were hydrated but stopped shortly after precipitation ended and the stromata dried. When the stromata was rewetted, spores were released immediately, but there was a lag of 3 to $5 \mathrm{~h}$ before the maximum rate of spore release was reestablished, regardless of the amount of time since the previous period of precipitation. Results similar to these field observations have been obtained when stromata were wetted intermittently under controlled conditions (J. Pinkerton, unpublished data). Ascospores were collected only rarely during periods of dew because, most likely, dew is insufficient to hydrate the perithecia, which are imbedded in a dense stroma (9).

Hourly collections of ascospores were dependent on the amount of time elapsed since the beginning of a precipitation event. In this regard, precipitation events could be characterized as being of one of two types: either brief, showery periods with average durations of 4 to $5 \mathrm{~h}$ or major rain storms with average durations of 17 to $20 \mathrm{~h}$. Most ascospores (>90\%) were released during the latter type of precipitation event, and the highest numbers of spores were collected between the fifth and twelfth hours after the start of precipitation. These extended periods of free moisture also favor the infection of hazelnut shoots $(16,31)$. No strong relationships, however, were observed between the release of ascospores of $A$. anomala and the other environmental parameters that we measured. Even though temperature has been shown to affect the rate of maturation and release of ascospores of $A$. anomala under con-

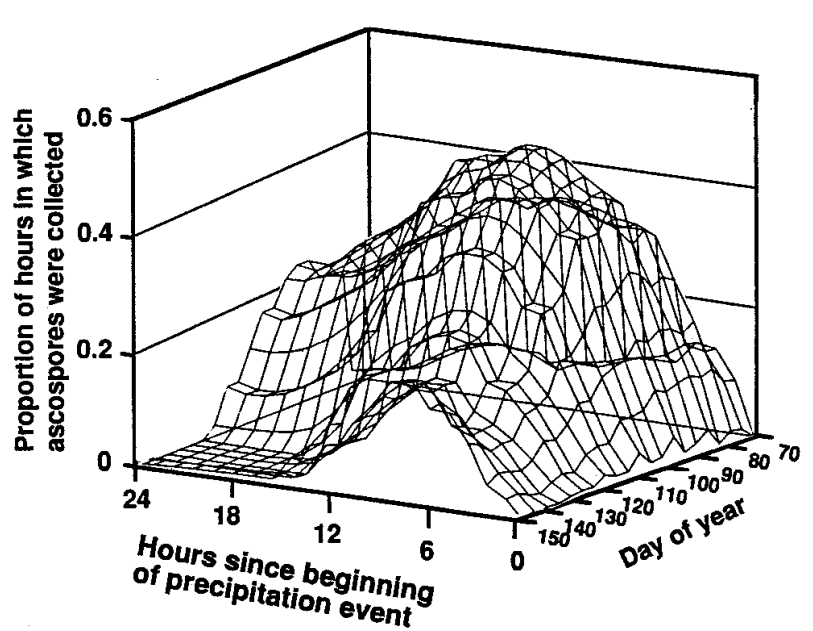

Fig. 3. Seasonal pattern of proportion of hours during which ascospores of Anisogramma anomala were collected in Burkhard volumetric spore traps in relation to day of year and hours since the beginning of a precipitation event. Data are from 243 precipitation events that were monitored in four diseased European hazelnut orchards in the northern Willamette Valley of Oregon from about 10 March to 1 June in 1992 and 1993. Equation for the response surface is $y=-1.8+0.39 d+0.056 h-0.00019 d^{2}-0.0020 h^{2}-0.00012 d h$ $\left(R^{2}=0.39\right)$, where $y=$ proportion of hours during which spores were captured, $d=$ day of year, and $h=$ hours since the beginning of a precipitation event. 
trolled conditions (J. Pinkerton, unpublished data), this effect was not strongly apparent in this field study in which the asci were mature at budbreak. Light is an important stimulus for triggering the release of spores of other fungi $(5,18,33)$, but this factor did not appear to influence release of ascospores of A. anomala.

Ascospores were captured during $>70 \%$ of precipitation events that exceeded $5 \mathrm{~h}$ in duration, the period required to reach maximum rate of spore release. Similarly, spores were captured during $>95 \%$ of events that exceeded $10 \mathrm{~h}$ and during all events that exceeded $20 \mathrm{~h}$. In our regression analysis, however, the independent variables hours of precipitation per day and hours of branch wetness per day accounted for only $35 \%$ of the variability in daily ascospore capture. At least part of the large component of unexplained variation may be attributable to significant factors that were observed but not included in this model. Ascospore production in A. anomala is determinant, and thus there is an important seasonal effect on the number of spores released during a precipitation event (Fig. 4). In addition, the distribution of spores captured within a precipitation event was not uniform from hour to hour. For example, events $>20 \mathrm{~h}$ in duration usually occurred over 2 days, and the majority of spores were captured before the fifteenth hour of rain. In these cases, the daily ascospore capture on the second day was lower than that on the preceding day. Therefore, a quantitative relationship between hours of precipitation and daily spore capture was evident, but variation introduced by seasonal effects and temporal variability within precipitation events made it difficult to develop a simple model with a high coefficient of determination.

Although release of ascospores of $A$. anomala can begin in late autumn when most asci are mature (25), European hazelnut is not susceptible to infection until vegetative buds and shoots resume active growth in the spring. Because spring weather in western Oregon is frequently conducive to infection, the pattern and magnitude of ascospore releases during the period when the host is susceptible to a large degree determines the amount of infection and when disease management inputs will be most effective. Previous to this study, the relationship between inoculum density and host infection had been examined only by artificial inoculation $(16,31)$. Missing from this relationship was how time of season and environment affected the availability of ascospore inoculum.

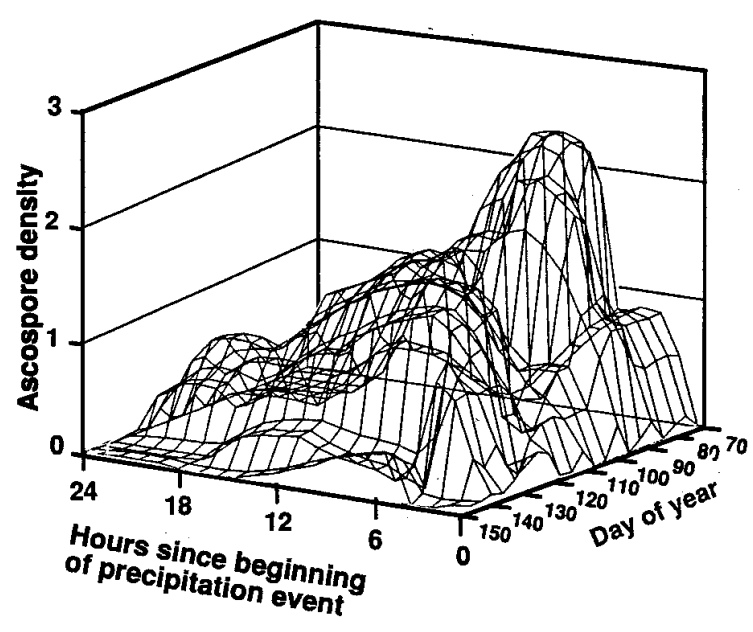

Fig. 4. Seasonal pattern of collection of ascospores of Anisogramma anomala in Burkhard volumetric spore traps in relation to day of year and hours since the beginning of a precipitation event. Data are from 243 precipitation events that were monitored in four diseased European hazelnut orchards in the northern Willamette Valley of Oregon from about 10 March to 1 June in 1992 and 1993. The equation for response surface is $y=-4.3+0.11 d+$ $0.047 h-0.00060 d^{2}-0.0057 h^{2}-0.00058 d h\left(R^{2}=0.43\right)$, where $y=$ hourly values of $\log _{10}\left(\right.$ ascospores $\left./ \mathrm{m}^{3}\right), d=$ day of year, and $h=$ hours since the beginning of a precipitation event.
The results of this study indicate that the likelihood of ascospore release was highest early in the period of host susceptibility. Furthermore, most spores were released during major storms, i.e., when branches were wet continuously for relatively long periods. During both years of this study, three major storms before 8 April (DOY 98) accounted of most (>83\%) of the ascospores captured at each site. As spring progressed, the likelihood of release of $A$. anomala ascospores declined because major rain storms occurred less frequently and because fewer viable ascospores remained in the perithecia (28; J. Pinkerton, unpublished data).

Knowledge of the factors affecting release of ascospores of $A$. anomala will be useful in management of eastern filbert blight in Oregon. The current recommendation for chemical control of this disease is to apply a fungicide at budbreak (mid-March) followed by additional applications every 12 to 14 days through mid-April $(15,17)$. Because of economic considerations, most growers are reluctant to apply fungicides more than twice. In this study, 76 to $90 \%$ of ascospores were released during the 4-week period after budbreak, which is about the maximum period of protection that can be expected from two fungicide treatments. Thus, for orchards planted to highly susceptible cultivars and at risk of infection, a third fungicide application may be warranted to prevent late (midApril) infection by A. anomala. Because major storms account for periods when most spores are discharged, this last fungicide application should be timed to provide protection prior to these major precipitation events.

\section{ACKNOWLEDGMENTS}

Research supported in part by the USDA-ARS and Oregon Agricultural Experiment Station Specific Cooperative Agreement 58-5358-190 and the Oregon Hazelnut Commission. Technical paper 11,182 of the Oregon Agricultural Experiment Station.

\section{LITERATURE CITED}

1. Alderman, S. C. 1993. Aerobiology of Claviceps purpurea in Kentucky bluegrass. Plant Dis. 77:1045-1049.

2. Aylor, D. E., and Anagnostakis, S. L. 1991. Active discharge distance of ascospores of Venturia inaequalis. Phytopathology 81:548-551.

3. Bertrand, P. F., and English, H. 1976. Release and dispersal of conidia and ascospores of Valsa leucostoma. Phytopathology 66:987-991.

4. Brook, P. J. 1969. Effects of light, temperature, and moisture on release of ascospores by Venturia inaequalis (Cke.) Wint. N.Z. J. Agric. Res. 12: 214-227.

5. Brook, P. J. 1969. Stimulation of ascospore release in Venturia inaequalis by far red light. Nature 222:390-392.

6. Davison, A. D., and Davidson, R. M., Jr. 1973. Apioporthe and Monchaetia canker reported in western Washington. Plant Dis. Rep. 57:522523.

7. Gadoury, D. M., and MacHardy, W. E. 1986. Forecasting ascospore dose of Venturia inaequalis in commercial apple orchards. Phytopathology 76:112-118.

8. Garcia, S. M., and Jones, A. L. 1993. Influence of temperature on apothecial development and ascospore discharge by Blumeriella jaapii. Plant Dis. 77:776-779.

9. Gottwald, T. R., and Cameron, H. R. 1979. Morphology and life history of Anisogramma anomala. Mycologia 71:1107-1126.

10. Gottwald, T. R., and Cameron, H. R. 1980. Disease increase and the dynamics of spread of canker caused by Anisogramma anomala in European filbert in the Pacific Northwest. Phytopathology 70:1087-1092.

11. Gottwald, T. R., and Cameron, H. R. 1980. Infection site, infection period, and latent period of canker caused by Anisogramma anomala in European filbert. Phytopathology 70:1083-1087.

12. Gregory, P. H., and Stedman, O. J. 1958. Spore dispersal in Ophiobolus graminis and other fungi of cereal foot-rots. Trans. Br. Mycol. Soc. 41: 449-456.

13. Hayes, A. J. 1980. Spore liberation in Grumenulopsis sororia. Trans. Br. Mycol. Soc. 74:27-40.

14. Ingold, C. T. 1971. Fungal Spores: Their Liberation and Dispersal. Clarendon Press, Oxford.

15. Johnson, K. B., Mehlenbacher, S. A., Stone, J. K., Pscheidt, J. W, and Pinkerton, J. N. 1996. Eastern filbert blight of European hazelnut: It's 
becoming a manageable disease. Plant Dis. 80:1308-1316.

16. Johnson, K. B, Pinkerton, J. N., Gaudreault, S. M., and Stone, J. K. 1994. Infection of European hazelnut by Anisogramma anomala: Site of infection and effect of host development stage. Phytopathology 84:14651470 .

17. Johnson, K. B., Pscheidt, J. W, and Pinkerton, J. N. 1993. Evaluation of chlorothalonil, fenarimol, and flusilazole for control of eastern filbert blight. Plant Dis. 77:831-837.

18. Leach, C. M. 1980. Influence of humidity, red-infrared radiation, and vibration on spore discharge by Pyricularia oryzae. Phytopathology 70:201-205.

19. Leach, C. M. 1980. Evidence for an electrostatic mechanism in spore discharge by Drechslera turcica. Phytopathology 70:206-213.

20. Linderman, R. G. 1974. Ascospore discharge from perithecia of Calonectria theae, C. crotalariae, and C. kyotessis. Phytopathology 64:567-569.

21. Luley, C. J., and McNabb, H. S., Jr. 1989. Ascospore production, release, germination, and infection of Populus by Mycosphaerella populorum. Phytopathology 79:1013-1018.

22. MacHardy, W. E., and Gadoury, D. M. 1986. Patterns of ascospore discharge by Venturia inaequalis. Phytopathology 76:985-990.

23. Madden, L. V. 1992. Rainfall and the dispersal of fungal spores. Adv. Plant Pathol. 8:39-79.

24. McCoy, R. E., and Dimock, A. W. 1973. Environment factors regulating ascospore discharge by Mycosphaerella ligulicola. Phytopathology 63: 586-589.
25. Pinkerton, J. N., Johnson, K. B., and Aylor, D. E. 1994. Release and dispersal of ascospores of Anisogramma anomala in European hazelnut plantings. (Abstr.) Phytopathology 84:1070.

26. Pinkerton, J. N., Johnson, K. B., Mehlenbacher, S. A., and Pscheidt, J. W. 1993. Susceptibility of European hazelnut clones to eastern filbert blight. Plant Dis. 77:261-266.

27. Pinkerton, J. N., Johnson, K. B., Theiling, K. M., and Griesbach, J. A. 1992. Distribution and characteristics of the eastern filbert blight epidemic in western Oregon. Plant Dis. 76:1179-1182.

28. Pinkerton, J. N., Stone, J. K., Nelson, S. J., and Johnson, K. B. 1995. Infection of European hazelnut by Anisogramma anomala: Ascospore adhesion, mode of penetration on immature shoots, and host response. Phytopathology 85:1260-1268.

29. Pusey, P. L. 1989. Availability and dispersal of ascospores and conidia of Botryosphaeria in peach orchards. Phytopathology 79:635-639.

30. Rowe, R. C., and Beute, M. K. 1975. Ascospore formation and discharge by Calonectria crotalariae. Phytopathology 65:393-398.

31. Stone, J. K., Johnson, K. B., Pinkerton, J. N., and Pscheidt, J. W. 1992. Natural infection period and susceptibility of vegetative seedlings of European hazelnut to Anisogramma anomala. Plant Dis. 76:348-352.

32. Sutton, T. B. 1981. Production and dispersal of ascospores and conidia by Physalospora obtusa and Botryosphaeria dothidea in apple orchards. Phytopathology 71:584-589.

33. Tate, K. G. 1979. Sclerotinia fructicola ascospore fluctuations in a peach orchard during blossom. N.Z. J. Agric. Res. 22:355-360. 